УДК 336.148

DOI https://doi.org/10.32837/pyuv.v2i4(29).453

\author{
B. В. Пацкан \\ orcid.org/0000-0002-9219-5380 \\ здобувач кафедри адліністративного, фінансового, інфорлаційного права \\ ДВНЗ «Ужгородський національний університет»
}

\title{
ВІДНОСИНИ РАХУНКОВОЇ ПАЛАТИ З ВЕРХОВНОЮ РАДОЮ УКРАЇНИ ТА ІІЇ КОМІТЕТАМИ
}

Постановка проблеми. У процесі розвитку України як правової і демократичної держави, євроінтеграції України, розвитку Рахункової палати як вищого органу аудиту України, запобігання та протидії корупції в Україні, адміністративної реформи важливого значення набуває дослідження проблеми відносин Рахункової палати з Верховною Радою України та її комітетами.

Дослідження проблеми відносин Рахункової палати з Верховною Радою України та її комітетами має важливе практичне значення для подальшого вдосконалення адміністративного законодавства України, а також для вдосконалення правозастосовної практики у цій сфері. Дослідження проблеми відносин Рахункової палати 3 Верховною Радою України та їі комітетами є важливим для розвитку науки адміністративного права.

Мета статті - охарактеризувати проблему відносин Рахункової палати з Верховною Радою України та її комітетами.

Завдання статті - сформулювати поняття «відносини Рахункової палати з іншими державними органами», охарактеризувати відносини Рахункової палати з Верховною Радою України та її комітетами.

Стан дослідження. Проблема відносин Рахункової палати з Верховною Радою України та її комітетами є актуальною, а окремі їі аспекти були предметом дослідження сучасних науковців, зокрема О. Койчевої, М. Крутевича, О. Ніконової, Н. Обушної, Ю. Табенської.

Виклад основного матеріалу. Відповідно до ст. 98 Конституції України [1] контроль від імені Верховної Ради України за надходженням коштів до Державного бюджету України та їх використанням здійснює Рахункова палата. Аналіз статусу та повноважень Рахункової палати України свідчить, що вона є не просто вищим за субординацією, а дійсно провідним органом державного фінансового контролю в Україні, який відповідає міжнародним стандартам. Це важливо з огляду на курс на євроінтеграцію [2, с. 157]. Отже, Рахункова палата є вищим органом аудиту в Україні.

Рахункова палата України як орган парламентського контролю згідно із конституційно затвердженими повноваженнями здійснює зовнішній контроль державних коштів [3]. Згідно зі ст. 1
Лімської декларації керівних принципів контролю державних фінансів запровадження контролю є невід’ємною складовою частиною управління публічними фінансовими ресурсами, яка забезпечує відповідальний та підзвітний характер цього управління [4]. Для виконання своїх завдань Рахункова палата як орган контролю використовує фінансовий контроль як спосіб, а для його реалізації виконує покладені на неї функції та використовує певні методи [5, с. 196].

Згідно зі ст. 4 Закону України «Про Рахункову палату» [6] повноваження, покладені на Рахункову палату Конституцією України, здійснюються через провадження заходів державного зовнішнього фінансового контролю (аудиту).

Відповідно до ч. 4 ст. 363 Закону України «Про аудит фінансової звітності та аудиторську діяльність» [7] державний фінансовий аудит здійснюється Рахунковою палатою та органами державного фінансового контролю згідно із законом.

Головним об’єктом контрольної діяльності Рахункової палати є державний бюджет. Щодо нього застосовується як наступний, так і попередній контроль, проводиться перевірка своєчасності виконання за обсягами, структурою і цільовим призначенням обгрунтованості дохідних і видаткових статей, ефективності і доцільності витрат державних коштів [8, с. 10].

У процесі практичної діяльності щодо здійснення своїх повноважень Рахункова палата, її члени та посадові особи вступають часто у правовідносини з іншими органами державної влади. Також існує специфіка контрольної діяльності і взаємовідносин Рахункової палати з об'єктами контролю та їх посадовими особами при провадженні заходів державного зовнішнього фінансового контролю (аудиту), що здійснюються Рахунковою палатою як вищим органом аудиту України, що заслуговує на окреме дослідження.

Отже, відносини Рахункової палати 3 іншими державними органами України - це суспільні відносини, врегульовані нормами права, з питань здійснення встановлених чинним законодавством України повноважень Рахунковою палатою та іншими державними органами України, що знаходять своє вираження у взаємних правах та обов'язках відповідних учасників правовідносин. 
Відносини Рахункової палати з іншими державними органами України можна поділити на такі основні групи:

1) відносини Рахункової палати з Верховною Радою України та ї̈ комітетами;

2) відносини Рахункової палати з Президентом України;

3) відносини Рахункової палати з Кабінетом Міністрів України;

4) відносини Рахункової палати з органом державного фінансового контролю;

5) відносини Рахункової палати з правоохоронними органами.

Відносини Рахункової палати з Верховною $\mathrm{Pa}$ дою України та ї̈ комітетами ми розглянемо нижче більш детально.

Згідно зі ст. 37 Закону України «Про Рахункову палату» Рахункова палата взаємодіє з Верховною Радою України та її органами в порядку, визначеному цим Законом, Регламентом Верховної Ради України та іншими законами. Така взаємодія передбачає, зокрема:

- призначення і звільнення Верховною Радою України Голови та інших членів Рахункової палати;

- інформування Верховної Ради України та ії органів про результати здійснення Рахунковою палатою заходів державного зовнішнього фінансового контролю (аудиту);

- подання і представлення Верховній Раді України щорічного звіту про результати діяльності Рахункової палати;

- заслуховування Верховною Радою України та їі органами доповідей та інформацій (повідомлень) членів Рахункової палати щодо здійснення заходів державного зовнішнього фінансового контролю (аудиту);

- надання Рахунковою палатою в межах її компетенції консультацій Верховній Раді України;

- участь народних депутатів України у засіданнях Рахункової палати;

- участь членів Рахункової палати у засіданнях Верховної Ради України та її органів.

Рахункова палата підзвітна Верховній Раді України та здійснює контроль від імені Верховної Ради України за надходженням коштів до Державного бюджету України та їх використанням. Верховна Рада України призначає на посади та звільняє з посад членів Рахункової палати відповідно до вимог Закону України «Про Рахункову палату» та в порядку, встановленому Регламентом Верховної Ради України. Рахункова палата в межах компетенції надає консультації Верховній Раді України за її зверненням.

Відповідно до п. 41.1. Регламенту Рахункової палати [9] вона регулярно інформує Верховну Раду України про результати здійснення заходів державного зовнішнього фінансового контролю (аудиту), включаючи факти порушень бюджетного законодавства.

Інформування Верховної Ради України здійснюється протягом 15 робочих днів з моменту затвердження Рахунковою палатою звіту та/або висновків, складених за результатами здійснення заходу державного зовнішнього фінансового контролю (аудиту), шляхом направлення листа за підписом Голови Рахункової палати, додатками до якого є копія рішення Рахункової палати, копія затвердженого звіту та інші матеріали (за необхідності).

Важливе значення у вищезгаданому контексті має також щорічний звіт про діяльність Рахункової палати. Вона щороку готує та не пізніше 1 травня року, наступного за звітним, подає Верховній Раді України щорічний звіт про свою діяльність.

Структурний підрозділ, відповідальний за питання аналітики, методології та контролю якості, на підставі матеріалів щодо здійснених заходів державного зовнішнього фінансового контролю (аудиту), наданих департаментами та іншими структурними підрозділами з питань діяльності Рахункової палати, підготовлених за окремим розпорядженням Голови Рахункової палати, готує проєкт щорічного звіту про діяльність Рахункової палати і подає його на розгляд Голові Рахункової палати, який вносить звіт на засідання Рахункової палати. Звіт після розгляду доопрацьовується з урахуванням висловлених зауважень та пропозицій.

Затверджений на засіданні і підписаний Головою Рахункової палати звіт про діяльність відповідно до статті 30 Закону подається до Верховної Ради України.

Одночасно із поданням звіту про діяльність Рахункової палати Верховній Раді України його електронна версія надається структурним підрозділом, відповідальним за питання аналітики, методології та контролю якості, структурному підрозділу, відповідальному за питання інформаційних ресурсів та технологій, для подальшого розміщення у форматі пдф-файла на вебсайті $\mathrm{Pa}$ хункової палати для відкритого доступу у формі відкритих даних відповідно до Закону України «Про доступ до публічної інформації».

Рахункова палата за дорученням Верховної Ради України проводить експертизу проєкту закону «Про Державний бюджет України» на наступний рік та за результатами проведеної експертизи складає у встановленому порядку висновок. Цей висновок затверджується Рахунковою палатою. Рахункова палата подає Верховній Раді України висновки, прийняті за результатами проведення експертизи проєкту закону «Про Державний бюджет України" на наступний рік. Голова Рахункової палати або за рішенням Рахункової палати 
інший їі член представляє Рахункову палату на пленарному засіданні Верховної Ради України під час обговорення у першому читанні проєкту закону «Про Державний бюджет України» на наступний рік та має право на виступ.

Рахункова палата у встановленому порядку подає Верховній Раді України такі документи:

- щоквартально висновки про стан виконання Закону «Про Державний бюджет України», а також пропозиції щодо усунення виявлених відхилень і порушень;

- висновки та пропозиції до річного звіту про виконання Закону «Про Державний бюджет України», поданого Кабінетом Міністрів України, з оцінкою ефективності управління коштами державного бюджету.

Важливе значення мають також відносини Рахункової палати з комітетами Верховної Ради України. Комітети Верховної Ради України на своїх засіданнях регулярно розглядають інформацію про результати аудитів, проведених Рахунковою палатою. Зокрема, Комітет Верховної Ради України з питань соціальної політики, зайнятості та пенсійного забезпечення на засіданні 18.01.2017 p. заслухав інформацію Рахункової палати щодо результатів аудиту проєкту «Модернізація соціальної підтримки населення України», що підтримувався коштами Міжнародного банку реконструкції та розвитку. Було ухвалене рішення рекомендувати Кабінету Міністрів України заслухати на засіданні Уряду питання стану виконання цього проєкту, доручити Міністерству соціальної політики України вжити заходів щодо реформування дитячих інтернатних закладів, запровадити ефективну систему моніторингу та оцінювання результатів проєкту, провести інвентаризацію та аналіз стану закупівель і використання обладнання, придбаного в рамках проєкту «Модернізація соціальної підтримки населення України» .

На засіданні 01.11.2017 р. Комітет Верховної Ради України у закордонних справах розглянув інформацію Рахункової палати про результати аудиту ефективності використання коштів Державного бюджету України на забезпечення у 2015-2016 роках Міністерством закордонних справ України функціонування закордонних дипломатичних установ України. Було прийняте рішення результати аудиту та стан реагування Міністерства закордонних справ України на рішення та пропозиції Рахункової палати розглядати в закритому режимі, оскільки матеріалам аудиту був присвоєний гриф «Для службового користування».

Комітет Верховної Ради України з питань культури і духовності на своєму засіданні 12.07.2017 p. розглянув інформацію Рахункової палати про результати аудиту ефективності використання бюджетних коштів на забезпечення діяльності
Національної академії мистецтв України. Результати аудиту Рахункової палати взято до відома. Рекомендовано вжити заходів щодо усунення порушень, встановлених аудитом [10].

Під час розгляду питань за результатами здійснених Рахунковою палатою заходів державного зовнішнього фінансового контролю (аудиту) на засіданнях комітетів Верховної Ради України Головою та членами Рахункової палати постійно наголошується на посиленні парламентського контролю за виконанням рішень Рахункової палати.

У 2018 році представники Рахункової палати взяли участь у 96 засіданнях комітетів Верховної Ради України, на яких було розглянуто 50 питань щодо діяльності Рахункової палати, з них 35 - за результатами здійснених Рахунковою палатою контрольних заходів на 3 парламентських слуханнях та на 52 засіданнях робочих груп. Розгляд i обговорення комітетами Верховної Ради України результатів проведених заходів державного зовнішнього фінансового контролю (аудиту) та реагування на рішення Рахункової палати сприяли реалізації наданих Рахунковою палатою рекомендацій об’єктам контролю, зокрема органам виконавчої влади. Протягом 2018 року питання щодо діяльності Рахункової палати та здійснених нею контрольних заходів розглядалися такими комітетами Верховної Ради України:

- комітетом з питань бюджету (17 питань);

- комітетом з питань екологічної політики, природокористування та ліквідації наслідків Чорнобильської катастрофи (10 питань);

- комітетом з питань охорони здоров'я (5 питань);

- комітетом з питань державного будівництва, регіональної політики та місцевого самоврядування (5 питань);

- комітетом з питань сім’ї, молодіжної політики, спорту та туризму (3 питання);

- комітетом 3 питань правової політики та правосуддя (2 питання);

- комітетом з питань аграрної політики та земельних відносин (2 питання);

- комітетом соціальної політики, зайнятості та пенсійного забезпечення (1 питання);

- комітетом з питань інформатизації та зв'язку (1 питання);

- комітетом з питань економічної політики (1 питання);

- комітетом 3 питань культури і духовності (1 питання);

- комітетом у закордонних справах (1 питання);

- спеціальною комісією Верховної Ради України з питань приватизації (1 питання).

Представники Рахункової палати брали участь за запрошеннями комітетів Верховної Ради України: 
- у 2 засіданнях комітету 3 питань науки і освіти;

- у 2 засіданнях комітету з питань паливноенергетичного комплексу, ядерної політики та ядерної безпеки;

- у 1 засіданні комітету з питань будівництва, містобудування і житлово-комунального господарства;

- у 1 засіданні комітету з питань законодавчого забезпечення та правоохоронної діяльності.

Упродовж 2018 року Рахункова палата кардинально змінила організацію співпраці з Комітетом Верховної Ради України з питань бюджету, надаючи звіти, висновки та інформацію, що були використані при проведенні оцінки показників державного та місцевих бюджетів на стадії їх формування та виконання. Представники Рахункової палати взяли участь у 21 засіданні Комітету, 30 засіданнях підкомітету та 51 засіданні робочих груп при підготовці проєкту закону України «Про Державний бюджет України на 2019 рік». Народні депутати - члени Комітету - регулярно запрошувались на засідання Рахункової палати і брали участь в обговоренні найбільш актуальних питань.

Комітет Верховної Ради України з питань бюджету на засіданні:

- 6 червня 2018 року розглянув Звіт Рахункової палати за 2017 рік та надав низку рекомендацій Рахунковій палаті, спрямованих на удосконалення iï діяльності, посилення взаємодії з Верховною Радою України та інформування громадськості. На цьому ж засіданні були розглянуті Висновки Рахункової палати про виконання Закону України «Про Державний бюджет України на 2017 рік». Ці висновки були використані при підготовці поданого до Верховної Ради України проєкту постанови Верховної Ради України «Про звіт «Про виконання Закону України «Про Державний бюджет України на 2017 рік», де пропонувалося доручити Кабінету Міністрів України вжити заходів щодо недопущення порушень бюджетного законодавства у 2018 році та наступних бюджетних періодах, а також щодо реалізації відповідних пропозицій Рахункової палати;

- 19 грудня 2018 року розглянув Висновок Рахункової палати про стан виконання Закону «Про Державний бюджет України на 2018 рік» у січні вересні та інформацію щодо виконання державного бюджету в поточному році. За результатами розгляду було прийняте рішення надати відповідні рекомендації Кабінету Міністрів України щодо забезпечення належного виконання державного бюджету у 2018 та 2019 роках [11].

На засіданнях Комітету Верховної Ради України з питань аграрної політики та земельних відносин 15 березня 2018 року розглянуто інформацію про результати проведеного Рахунковою палатою аудиту ефективності використання коштів державного бюджету, спрямованих на реалізацію державної політики 3 питань безпечності харчових продуктів та захисту споживачів. Враховуючи пропозиції Рахункової палати, Комітет надав Кабінету Міністрів України низку рекомендацій щодо розроблення та прийняття нормативно-правових актів з питань безпечності харчових продуктів та захисту споживачів, прискорення внесення на розгляд Верховної Ради України законопроєктів щодо внесення змін до законів України «Про основні принципи та вимоги до безпечності та якості харчових продуктів» [12], «Про ветеринарну медицину» [13], «Про захист прав споживачів» [14], «Про забезпечення санітарного та епідемічного благополуччя населення» [15] та «Про основні засади державного нагляду (контролю) у сфері господарської діяльності» [16]. Крім того, Комітет рекомендував Міністерству аграрної політики та продовольства України і Державній службі України з питань безпечності харчових продуктів та захисту споживачів вжити заходів щодо врегулювання питання штатної чисельності державних фітосанітарних інспекторів головних управлінь Держпродспоживслужби в областях та їх постійного перебування у митницях для безперебійного оформлення вантажів в інформаційній системі «Єдине вікно», інспекторів регіональних служб державного ветеринарно-санітарного контролю та нагляду на державному кордоні і транспорті, а також прискорення процедур реорганізації (ліквідації) територіальних органів, установ та підприємств, що перебували у віданні центральних органів виконавчої влади, які були реорганізовані при створенні Держпродспоживслужби та перебувають на тимчасово окупованих територіях.

На засіданні Комітету Верховної Ради України 3 питань державного будівництва, регіональної політики та місцевого самоврядування:

- 6 червня 2018 року розглянуто інформацію Рахункової палати щодо результатів аудиту ефективності використання коштів державного бюджету, виділених Національному агентству України з питань державної служби на професійне навчання державних службовців та посадових осіб місцевого самоврядування. За підсумками розгляду Комітет прийняв рішення рекомендувати Кабінету Міністрів України вжити заходів щодо нормативного врегулювання порушених у звіті Рахункової палати питань професійного навчання державних службовців і посадових осіб місцевого самоврядування;

- 20 червня 2018 року Комітет заслухав інформацію Рахункової палати щодо результатів аудиту ефективності використання коштів державного бюджету на створення і забезпечення функціонування центрів надання адміністративних послуг. Прийнято рішення звернутися до Кабінету 
Міністрів України, висловивши позицію Комітету про необхідність надання усіх послуг населенню тільки через центри надання адміністративних послуг, утворені відповідно до Закону України «Про адміністративні послуги», і неприйнятність створення паралельних структур для надання послуг окремими органами виконавчої влади.

Комітет Верховної Ради України з питань екологічної політики, природокористування та ліквідації наслідків Чорнобильської катастрофи на засіданні 16 січня 2018 року розглянув інформацію Рахункової палати про результати аудиту ефективності використання коштів державного бюджету, спрямованих на розвиток та функціонування системи протипаводкового захисту. Комітет прийняв рішення рекомендувати Кабінету Міністрів України вжити заходів щодо забезпечення міжвідомчої та регіональної координації при виконанні заходів Загальнодержавної цільової програми розвитку водного господарства та екологічного оздоровлення басейну річки Дніпро на період до 2021 року та забезпечити у 2018 році та у наступних роках належне фінансування протипаводкових заходів, визначених у цій програмі.

22 травня 2018 року розглянуто такі питання за результатами контрольних заходів Рахункової палати:

- щодо результатів аналізу стану виконання рекомендацій Міжнародного координованого аудиту Чорнобильського фонду «Укриття». Комітет рекомендував Кабінету Міністрів України, Міністерству екології та природних ресурсів України, Державному агентству України з управління зоною відчуження та Державному спеціалізованому підприємству «Чорнобильська AEC» усунути виявлені аудитом порушення та недоліки, прискорити введення в експлуатацію нового безпечного конфаймента, другого проміжного сховища відпрацьованого ядерного палива «сухого» типу, заводу з переробки рідких радіоактивних відходів, промислового комплексу поводження з твердими радіоактивними відходами та забезпечити дієвий контроль за дотриманням графіків виконання робіт і кошторисів видатків міжнародних проєктів, що реалізуються на майданчику Чорнобильської AEC, а також забезпечити довгострокове та стабільне фінансування зняття з експлуатації Чорнобильської AEC і перетворення об'єкта «Укриття» на екологічно безпечну систему шляхом створення у складі Державного бюджету України спеціалізованого фонду або за рахунок вже існуючих фондів;

- щодо результатів аудиту ефективності використання Міністерством екології та природних ресурсів України коштів державного бюджету за бюджетною програмою «Прикладні наукові та науково-технічні розробки, виконання робіт за державними цільовими програмами і державним замовленням у сфері природоохоронної діяльності, фінансова підтримка підготовки наукових кадрів». Прийнято рішення рекомендувати Мiністерству екології та природних ресурсів України забезпечити приведення у відповідність із Законом України «Про наукову і науково-технічну діяльність» [17] нормативно-правових актів та власних актів щодо фінансування окремих наукових і науково-технічних програм і проєктів, виконавцями яких $є$ установи, що належать до сфери управління Міністерства, а також визначити пріоритетні напрями наукових досліджень у галузі охорони навколишнього природного середовища і забезпечити виконання Указу Президента України «Про оголошення природної акваторії Чорного моря ботанічним заказником загальнодержавного значення "Філофорне поле Зернова" [18] в частині оформлення охоронного зобов'язання цього заказника відповідно до статті 53 Закону України «Про природно-заповідний фонд України» [19].

6 вересня 2018 року розглянуто результати міжнародного координованого аудиту функціонування біосферного заповідника «Східні Карпати» і рекомендовано Кабінету Міністрів України надати відповідні доручення зацікавленим органам щодо розробки проєкту та укладання міжурядової або міжміністерської угоди про створення та функціонування міжнародного біосферного заповідника «Східні Карпати» [11].

Висновки. Отже, поняття «відносини Рахункової палати з іншими державними органами України» можна визначити як суспільні відносини, врегульовані нормами права, з питань здійснення встановлених чинним законодавством України повноважень Рахунковою палатою та іншими державними органами України, що виражаються у взаємних правах та обов'язках відповідних учасників правовідносин.

3 метою ефективної роботи Рахункової палати як вищого органу аудиту України, забезпечення високого рівня довіри з боку суспільства, інших органів державної влади, міжнародного співтовариства, вищих органів аудиту окремих зарубіжних країн важливим є забезпечення належних відносин Рахункової палати з іншими державними органами України, що є гарантією для належного здійснення публічного контролю за надходженням коштів до Державного бюджету України та їх використанням.

Існують перспективи подальших наукових досліджень у даному напрямі щодо порівняльно-правового аналізу статусу вищих органів аудиту, державного фінансового контролю, адміністративно-правового статусу Рахункової палати.

Отже, у даній статті охарактеризовано проблему правовідносин Рахункової палати з Верховною Радою України та іï комітетами. 


\section{Jimepamypa}

1. Конституція України : Закон України від 28 червня 1996 року. Відомості Верховної Ради України. 1996. № 30. Ст. 141.

2. Койчева О.С. Конституційний статус рахункової палати України в системі органів державного фінансового контролю. Право і суспільство. 2014. № 6.1 . C. $151-158$.

3. Табенська Ю.В. Делеговані контрольні повноваження Рахункової палати України. URL: http://sophus.at.ua/publ/2015_06_4_5_kam podils/sekcija section $3 \quad 201506 \quad 4 \quad \overline{5} /$ delegovani $^{-}$ kontrolni_povnovazhēnnja_rākhūn $\bar{k}$ ovoji_palati ukrajini/9 $\overline{9}-1-0-1470$ (дата звернення: 23 вересня $201 \overline{9}$ року).

4. The Lima Declaration (ISSAI 1). (1977), Approved at IXth Congress of INTOSAI, Lima/Peru, "INTOSAI Professional Standards Committee". URL: http://www.issai.org/media/12901/issai_1_e.pdf (дата звернення: 23 вересня 2019 року).

5. Койчева О.С. Фінансовий контроль як спосіб реалізації повноважень Рахункової палати. Держава $i$ право. Серія «Юридичні і політичні науки». 2014. Вип. 65. C. 192-198.

6. Про Рахункову палату : Закон України від 2 липня 2015 року. Відомості Верховної Ради Украӥни. 2015. № 36. Ст. 360.

7. Про аудит фінансової звітності та аудиторську діяльність : Закон України від 21 грудня 2017 року. Відомості Верховної Ради України. 2018. № 9. Ст. 50.

8. Крутевич М.М. Конституційно-правові основи діяльності Рахункової палати в Україні. Окремі аспекти. Юридична наука. 2015. № 7. С. 7-13.

9. Регламент Рахункової палати, затверджений рішенням Рахункової палати від 28.08.2018 р. № 22-7. URL: https://rp.gov.ua/upload-files/About/ RegulatoryDoc/arp_1_new.pdf (дата звернення: 24 вересня 2019 року).

10. Звіт Рахункової палати за 2017 рік, затверджений Рішенням Рахункової палати від 22.03.2018 р. № 7-2. URL: https://rp.gov.ua/upload-files/Activity/ Reports/Zvit_RP_2017.pdf (дата звернення: 24 вересня 2019 року)

11. Звіт Рахункової палати за 2018 рік. URL: https://rp.gov.ua/upload-files/Activity/Reports/2018/ ZVIT_RP_2018.pdf (дата звернення: 24 вересня 2019 року).

12. Про основні принципи та вимоги до безпечності та якості харчових продуктів : Закон України від 23 грудня 1997 року. Відомості Верховної Ради України. 1998. № 19. Ст. 98.

13. Про ветеринарну медицину : Закон України в редакції від 16.11.2006 року. Відомості Верховної Ради України. 2007. № 5-6. Ст. 53.

14. Про захист прав споживачів : Закон України в редакції від 01.12.2005 року. Відомості Верховної Ради України. 2006. № 7. Ст. 84.

15. Про забезпечення санітарного та епідемічного благополуччя населення : Закон України від 24 лютого 1994 року. Відолості Верховної Ради України. 1994. № 27. Ст. 218.

16. Про основні засади державного нагляду (контролю) у сфері господарської діяльності : Закон України від 5 квітня 2007 року. Відолості Верховной Ради України. 2007. № 29. Ст. 389.

17. Про наукову і науково-технічну діяльність : Закон України від 26 листопада 2015 року. Відолості Верховної Ради України. 2016. № 3. Ст. 25.

18. Про оголошення природної акваторії Чорного моря ботанічним заказником загальнодержавного значення «Філофорне поле Зернова» : Указ Президента України №1064/2008. URL: https://www.president. gov.ua/documents/10642008-8223 (дата звернення: 25 вересня 2019 року).

19. Про природно-заповідний фонд України : Закон України від 16 червня 1992 року. Відомості Верховної Ради України. 1992. № 34. Ст. 502.

\section{Анотація}

Пацкан В. В. Відносини Рахункової палати з Верховною Радою України та ії комітетами. - Стаття.

Статтю присвячено проблемі відносин Рахункової палати з Верховною Радою України та їі комітетами. Сформульовано поняття «відносини Рахункової палати 3 іншими державними органами». Охарактеризовано відносин Рахункової палати з Верховною Радою України та її комітетами. З'ясовано, що затверджений на засіданні і підписаний Головою Рахункової палати звіт про діяльність Рахункової палати відповідно до статті 30 Закону подається до Верховної Ради України. Одночасно із поданням звіту про діяльність Рахункової палати Верховній Раді України його електронна версія надається структурним підрозділом, відповідальним за питання аналітики, методології та контролю якості, структурному підрозділу, відповідальному за питання інформаційних ресурсів та технологій, для подальшого розміщення на вебсайті Рахункової палати для відкритого доступу у формі відкритих даних відповідно до Закону України «Про доступ до публічної інформації». Визначено, що рахункова палата за дорученням Верховної Ради України проводить експертизу проєкту закону «Про Державний бюджет України» на наступний рік та за результатами проведеної експертизи складає у встановленому порядку висновок. Зроблено висновок, що поняття «відносини Рахункової палати з іншими державними органами України» можна визначити як суспільні відносини, врегульовані нормами права, з питань здійснення встановлених чинним законодавством України повноважень Рахунковою палатою та іншими державними органами України, що виражаються у взаємних правах та обов'язках відповідних учасників правовідносин. 3 метою ефективної роботи Рахункової палати як вищого органу аудиту України, забезпечення високого рівня довіри з боку суспільства, інших органів державної влади, міжнародного співтовариства, вищих органів аудиту окремих зарубіжних країн важливим є забезпечення належних відносин Рахункової палати з іншими державними органами України, що є гарантією належного здійснення публічного контролю за надходженням коштів до Державного бюджету України та їх використанням.

Ключові слова: Рахункова палата, вищий орган аудиту, державна влада, Верховна Рада України, комітети Верховної Ради України, фінансовий контроль, аудит.

\section{Summary}

Patskan V. V. Relations of the Accounting Chamber with the Verkhovna Rada of Ukraine and its committees. - Article.

The article is devoted to the problems of relations of the Accounting Chamber with the Verkhovna Rada of Ukraine and its committees. The concept of "relations of the Accounting Chamber with other state bodies" is formulated. The relations of the Accounting Chamber with the Verkhovna Rada of Ukraine and its committees are characterized. It is found out that the report on the activity of the Accounting Chamber approved in accordance with 
Article 30 of the Law, approved and approved by the Chairman of the Accounting Chamber, is submitted to the Verkhovna Rada of Ukraine. Simultaneously with the submission of the Accounting Chamber activity report to the Verkhovna Rada of Ukraine, its electronic version is provided to the structural unit responsible for analytics, methodology and quality control, the structural unit responsible for information resources and technologies for further placement on the website of the Accounting Chamber for the public, access in the form of open data in accordance with the Law of Ukraine "On Access to Public Information". It has been determined that the Accounts Chamber, on behalf of the Verkhovna Rada of Ukraine, carries out an examination of the draft law on the State Budget of Ukraine for the next year and draws a conclusion in accordance with the established procedure. The opinion, drawn on the results of the examination of the draft law on the State Budget of Ukraine for the next year, is approved. It is concluded that the concept of "relations of the
Accounting Chamber with other state bodies of Ukraine" can be defined as public relations governed by the rules of law on the exercise of the powers established by the current legislation of the Accounting Chamber and other state bodies of Ukraine, which are expressed in mutual rights and obligations relations of the relevant participants in the relationship. In order for the Accounting Chamber to function effectively as the supreme audit body of Ukraine, to ensure a high level of trust on the part of the public, other public authorities, the international community, and the higher audit bodies of certain foreign countries, it is important to ensure the proper relations of the Accounting Chamber with other state bodies of Ukraine an important guarantee for the proper exercise of public control over the receipt and use of funds to the State Budget of Ukraine.

Key words: Accounting Chamber, Supreme Audit Institution, the state government, Verkhovna Rada of Ukraine, Committees of Verkhovna Rada of Ukraine, financial control, audit. 